STUDIA I PRACE WYDZIAŁU NAUK EKONOMICZNYCH I ZARZĄDZANIA nr 40, t. 1

Edyta Mioduchowska-Jaroszewicz*

Tomasz Bednarz

Elżbieta Ziółkowska ${ }^{* * x}$

Uniwersytet Szczeciński

\title{
DIAGNOZA POZYCJI FINANSOWEJ SPÓŁEK GIEŁDOWYCH METODĄ QUICK TESTU
}

\section{Streszczenie}

Celem artykułu jest zweryfikowanie przydatności zastosowania metody quick testu do oceny sytuacji finansowej na podstawie dwóch grup przedsiębiorstw: 37 „dobrych” i 37 ,złych”. Przedsiębiorstwa przyjęte do bazy „dobrych” charakteryzowały się osiąganiem zysku, natomiast przedsiębiorstwa „złe” postawione były w stan upadłości. Teza badawcza postawiona $\mathrm{w}$ artykule stwierdzała, że metoda quick testu z wybranymi czterema wskaźnikami (samofinansowania, stopnia pokrycia odsetek, rentowności aktywów i poziomu kosztów) daje możliwość prawidłowej oceny kondycji finansowej przedsiębiorstw. W wyniku przeprowadzonych badań stwierdzono, że teza ta jest fałszywa, co oznacza, że metoda quick testu z wybraną grupą wskaźników nie daje możliwości prawidłowego zdiagnozowania kondycji finansowej przedsiębiorstw.

Słowa kluczowe: pozycja finansowa, metoda quick testu, wskaźniki finansowe, spółki giełdowe

\footnotetext{
* Adres e-mail: emioduch@wneiz.pl.

** Adres e-mail: bednarz.tomasz42@gmail.com.

*** Adres e-mail: e.ziolkowskaa@gmail.com.
} 


\section{Wprowadzenie}

Analiza danych finansowych spółek giełdowych z punktu widzenia ich efektywności na rynkach finansowych jest bardzo ważna. Analiza wskaźnikowa jest tradycyjnym sposobem oceny, będącym - mimo wielu ograniczeń i zakłóceń porównywalności - ważnym instrumentem badania danych finansowych spółek giełdowych. Istotność analizy fundamentalnej podkreślono, przyznając Nagrodę Nobla w 2013 roku R. Shillerowi za badania, które wykazały, że ceny akcji zawsze odzwierciedlają dostępne informacje na temat papierów wartościowych. Artykuł jest próbą pokazania zastosowania metody punktowej zwanej metodą quick testu w ocenie pozycji finansowej spółek giełdowych z wykorzystaniem czterech wskaźników finansowych. Celem artykułu jest zweryfikowanie przydatności zastosowania tej metody do oceny sytuacji finansowej na podstawie dwóch grup przedsiębiorstw: 37 „dobrych” i 37 „złych”. Przedsiębiorstwa zostały przyjęte do bazy „dobrych”, bo charakteryzowały się osiąganiem zysku. Do grupy przedsiębiorstw „złych” zaliczono firmy, które złożyły wniosek o upadłość. Teza badawcza postawiona w artykule brzmi następująco: metoda quick testu z wybranymi czterema wskaźnikami (samofinansowania, stopnia pokrycia odsetek, rentowności aktywów i poziomu kosztów) daje możliwość prawidłowej oceny kondycji finansowej przedsiębiorstw. W badaniach podjętych w artykule zastosowano metodę dedukcji, metodę analizy ilościowej, metodę analizy wskaźnikowej i metodę analizy skupień.

\section{Metodologia badawcza}

Metoda quick testu należy do metod punktowych ${ }^{1}$. Jest to metoda, która jest systemem wczesnego ostrzegania w działalności gospodarczej przedsiębiorstwa. Jej zadaniem jest identyfikacja zagrożeń występujących w tej działalności. Ma wytyczać kierunki dalszych szczegółowych badań ${ }^{2}$. W literaturze ekonomicznej została

${ }^{1}$ Szerzej E. Siemińska, Metody pomiaru i oceny kondycji przedsiębiorstwa, Wydawnictwo Uniwersytetu Toruńskiego im. Mikołaja Kopernika w Toruniu, Torun 2002; E. Mioduchowska-Jaroszewicz, Metody i kierunki analizy wyptacalności przedsiębiorstw, Wydawnictwo Naukowe Uniwersytetu Szczecińskiego, Szczecin 2005.

${ }^{2}$ E. Mioduchowska-Jaroszewicz, Zastosowanie quick testu do oceny spółek giełdowych sektora spożywczego, w: Perspektywy rozwoju rachunkowości, auditingu i analizy finansowej, red. J. Gierusz, Uniwersytet Gdański, Sopot 1999. 
po raz pierwszy przedstawiona przez E. Mączyńską ${ }^{3}$. Metoda ta opiera się na wykorzystaniu czterech wskaźników, które podobnie jak w modelu Altmana ${ }^{4}$ mają określić stabilność finansową przedsiębiorstwa, jego rentowność oraz zdolność do generowania nadwyżek pieniężnych. Wartości wskaźników są odnoszone do wielkości wzorcowych ${ }^{5}$. W badaniu zostały wykorzystane cztery wskaźniki finansowe, z przypisanymi im normami wartości, które zostały osadzone w praktyce gospodarczej i teorii naukowej. Przy doborze wskaźników kierowano się kryteriami oceny pozycji finansowej przedsiębiorstw, takie jak: zyskowność (rentowność), ryzyko, zadłużenie i płynność finansowa ${ }^{6}$. Zestaw wskaźników do oceny kondycji finansowej spółek giełdowych zaprezentowano w tabeli 1.

Tabela 1. Wskaźniki zastosowane do metody quick testu

\begin{tabular}{|l|l|}
\hline \multicolumn{1}{|c|}{ Nazwa } & \multicolumn{1}{c|}{ Formuła } \\
\hline Udział kapitału własnego w aktywach (W1) & Kapitał własny/aktywa \\
\hline Stopień pokrycia odsetek (W2) & Zysk operacyjny/odsetki \\
\hline Rentowność aktywów (W3) & Zysk netto/średnie aktywa \\
\hline Poziom kosztów (W4) & Koszty ogółem/przychody ogółem \\
\hline
\end{tabular}

Źródło: opracowanie własne.

Wskaźnik udziału kapitału własnego w aktywach nazywany jest też wskaźnikiem pokrycia majątku kapitałem własnym. Charakteryzuje on poziom finansowania kapitałem własnym badanych przedsiębiorstw. Niska wartość udziału kapitału własnego w finansowaniu majątku może być dla przedsiębiorstwa dużym ryzykiem finansowym związanym z koniecznością spłaty kredytów wraz z odsetkami. Wadą

3 E. Mączyńska, Ocena kondycji przedsiębiorstwa, „Życie Gospodarcze” 1994, nr 38.

${ }^{4}$ E. Mioduchowska-Jaroszewicz, Model Altmana jako jedna z metod oceny wypłacalności przedsiębiorstw, „Prace Instytutu Ekonomiki i Organizacji Przedsiębiorstw” nr 329, red. W. Janasz, Wydawnictwo Naukowe Uniwersytetu Szczecińskiego, Szczecin 2002.

5 Analiza finansowa przedsiębiorstwa, red. M. Hamrol, Wydawnictwo Akademii Ekonomicznej w Poznaniu, Poznań 2004, s. 202, 209-211.

${ }^{6}$ T. Waśniewski, W. Skoczylas, Syntetyczna ocena wyników oraz sytuacji finansowej przedsiębiorstwa, „Rachunkowość” 1998, nr 4, s. 19.

7 W. Gabrusewicz, Analiza finansowa przedsiębiorstwa. Teoria i zastosowanie, PWE, Warszawa 2014, s. 342-343. 
tego wskaźnika jest brak informacji na temat wahań zysków i przepływów pieniężnych, które mogą wpływać na zdolność do spłaty odsetek i rat kapitałowych ${ }^{8}$.

Wskazywana $\mathrm{w}$ literaturze norma dla tego wskaźnika kształtuje się w przedziale $0,33-0,43^{9}$. W praktyce gospodarczej jednak finansowanie działalności z kapitału własnego nie jest proste i zależy od wielu czynników ${ }^{10}$. Stopień pokrycia odsetek charakteryzuje krotność pokrycia zyskiem operacyjnym odsetek naliczonych od kapitałów obcych. Wskaźnik pokrycia odsetek informuje, ile razy środki uzyskane z działalności operacyjnej mogą pokryć odsetki. Wypłacalność przedsiębiorstwa jest tym lepsza, im większą wartość uzyskuje wskaźnik ${ }^{11}$. Za dobrą wartość wskaźnika uważa się 2,4 w wypadku kredytów zabezpieczonych. Dla kredytów niezabezpieczonych wielkość wzorcowa jest wyższa i wynosi 5,012. Wskaźnik może spadać albo osiągać niskie wartości w momencie, kiedy firma rozwija się. Jednak wartość wskaźnika nie powinna spaść poniżej 1. Osiągnięcie wartości tego wskaźnika poniżej jedności, wskazuje na brak możliwości spłaty odsetek przez przedsiębiorstwo ${ }^{13}$.

Kolejnym wskaźnikiem wybranym do quick testu jest rentowność aktywów, ukazująca syntetyczną, całościową ocenę efektywności majątku ustaloną na podstawie zysku netto ${ }^{14}$. Wartość wskaźnika jest uzależniona od specyfiki działalności sektora, zawsze dodatnia i posiadająca rosnącą tendencję jest uznawana za pozytywną.

Ostatnim wybranym wskaźnikiem do zastosowania metody quick testu jest wskaźnik poziomu kosztów, będący relacją kosztów do przychodów. W przypadku badań zaprezentowanych w artykule przedstawiono stosunek kosztów ogółem do przychodów ogółem. Rosnący poziom efektywności zużycia czynników produkcji

${ }^{8}$ E.A. Helfert, Techniki analizy finansowej, PWE, Warszawa 2004, s. 180.

${ }^{9}$ Ibidem, s. 79.

${ }^{10}$ E. Mioduchowska-Jaroszewicz, Poziom zadtużenia w spótkach sektora budowlanego, w: Zarządzanie finansami. Zarządzanie ryzykiem i kreowanie wartości, red. D. Zarzecki, Wydawnictwo Naukowe Uniwersytetu Szczecińskiego, Szczecin 2007, s. 109-116.

${ }^{11}$ T. Waśniewski, W. Skoczylas, Kierunki analizy finansowej w przedsiębiorstwie, Wyższa Szkoła Administracji Publicznej, Szczecin 1996, s. 69.

12 Szerzej G. Gołębiewski, A. Tłaczała, Analiza ekonomiczno-finansowa w ujęciu praktycznym, Difin, Warszawa 2005, s. 127.

13 T. Waśniewski, W. Skoczylas, Syntetyczna ocena..., s. 205.

${ }^{14}$ W. Gabrusewicz, op.cit., s. 312-313. 
odzwierciedla malejąca wartość tego wskaźnika ${ }^{15}$. Powinien on mieścić się w granicach $0,5-0,9$. Poziom tego wskaźnika przewyższający ten próg może świadczyć o trudnościach w pokryciu ponoszonych kosztów. Natomiast wskaźnik poniżej 0,5 świadczy o wysokiej zyskowności przedsiębiorstwa ${ }^{16}$. Aby stwierdzić, czy przedsiębiorstwo jest opłacalne, wartość wskaźnika powinna być mniejsza od 1 (jeżeli wskaźnik nie jest wyrażony w procentach) ${ }^{17}$.

W tabeli 2 zaprezentowano normy wskaźników przyjęte do zastosowania metody quick testu w diagnozie sytuacji finansowej spółek giełdowych.

Tabela 2. Zakres i normy oceny wskaźników w metodzie quick testu

\begin{tabular}{|l|c|c|c|c|c|}
\hline \multirow{2}{*}{ Nazwa wskaźnika } & \multicolumn{5}{|c|}{ Skala oceny dla wská́nika } \\
\cline { 2 - 6 } & $\begin{array}{c}\text { bardzo dobra } \\
5 \mathrm{pkt}\end{array}$ & $\begin{array}{c}\text { dobra } \\
4 \mathrm{pkt}\end{array}$ & $\begin{array}{c}\text { dostateczna } \\
3 \mathrm{pkt}\end{array}$ & $\begin{array}{c}\text { zła } \\
2 \mathrm{pkt}\end{array}$ & $\begin{array}{c}\text { bardzo zła } \\
1 \mathrm{pkt}\end{array}$ \\
\hline $\begin{array}{l}\text { Udział kapitału własnego } \\
\text { w aktywach (W1) }\end{array}$ & $\geq 0,50$ & $0,49-0,40$ & $0,39-0,30$ & $0,29-0,10$ & $0,09-0,00$ \\
\hline $\begin{array}{l}\text { Stopień pokrycia odsetek } \\
\text { (W2) }\end{array}$ & $>6,00$ & $6,00-4,00$ & $3,90-2,00$ & $2,00-1,00$ & $<1,00$ \\
\hline Rentowność aktywów (W3) & $>0,041$ & $0,031-0,041$ & $0,021-0,03$ & $0,011-0,02$ & $\leq 0,01$ \\
\hline Poziom kosztów (W4) & $<0,90$ & $0,95-0,90$ & $0,97-0,96$ & $0,98-0,99$ & $\geq 1,00$ \\
\hline
\end{tabular}

Źródło: opracowanie własne.

Na podstawie badań empirycznych i literaturowych wygenerowano normy wskaźników, które mogą być dyskusyjne i kontrowersyjne. Jednak próbując zastosować przedstawianą metodę, przyjęto punkty odniesienia wyprowadzone na podstawie własnych doświadczeń z praktyki gospodarczej i naukowej, które zaprezentowano w tabeli 3. Wszystkim wskaźnikom, które zostały przyjęte do metody, nadano taką samą wagę, dlatego wszystkie mają identyczną skalę ocen. W tabeli 3 zaprezentowano oceny wynikające z uzyskania odpowiedniej liczby punktów po zastosowaniu skali ocen z tabeli 2 .

15 T. Waśniewski, W. Skoczylas, Kierunki analizy finansowej..., s. 127-128.

${ }^{16}$ M. Sierpińska, T. Jachna, Ocena przedsiębiorstwa wedtug standardów światowych, PWE, Warszawa 2001, s. 95.

${ }^{17}$ Szerzej E. Urbańczyk, Metody ilościowe w analizie finansowej, Wydawnictwo Naukowe Uniwersytetu Szczecińskiego, Szczecin 1998, s. 165. 
Tabela 3. Ocena liczby zdobytych punktów w badaniu

\begin{tabular}{|c|l|}
\hline $\begin{array}{c}\text { Kryterium oceny } \\
- \text { liczba uzyskanych punktów }\end{array}$ & \multicolumn{1}{c|}{ Ocena wynikająca z liczby uzyskanych punktów } \\
\hline $17-20$ & kondycja finansowa bardzo dobra \\
\hline $13-16$ & kondycja finansowa dobra \\
\hline $9-12$ & kondycja finansowa dostateczna \\
\hline $5-8$ & kondycja finansowa zła/niekorzystna \\
\hline $0-4$ & kondycja finansowa bardzo zła \\
\hline
\end{tabular}

Źródło: opracowanie własne.

Na podstawie danych z tabeli 3 wyróżniono pięć poziomów kondycji finansowej, którą może charakteryzować się przedsiębiorstwo. Bardzo dobra kondycja finansowa wskazuje na wyróżniającą sytuację badanych firm, których pozycja jest stabilna i bezpieczna. Firmy te są bardzo zyskowne, mają niski poziom zadłużenia, posiadają płynność finansową i wypłacalność - są pewną lokatą kapitału. Dobra kondycja finansowa charakteryzuje firmy, które nie są zagrożone niewypłacalnością i upadłością, a nawet nagły spadek zysków czy utrata poważnego kontrahenta nie powinny zagrozić ich funkcjonowaniu. Dostateczna kondycja finansowa dotyczy firm znajdujących się w niepewnej sytuacji finansowej, mających problemy z wysokim poziomem zadłużenia, niską rentownością i nieradzących sobie $\mathrm{z}$ obsługą długu. Zła kondycja finansowa charakteryzuje przedsiębiorstwa, których sytuacja finansowa wskazuje na poważne problemy wynikające z braku rentowności i wysokiego poziomu zadłużenia. Bardzo złą kondycję finansową mają firmy niewypłacalne albo będące już w stanie upadłości.

\section{Zastosowanie metody quick testu w diagnozie pozycji finansowej spółek giełdowych}

Na podstawie 74 sprawozdań finansowych zawartych w raportach rocznych spółek giełdowych obliczono 4 wskaźniki dla każdej spółki (tabela 1), które odniesiono do norm zawartych w tabeli 2 i kryteriów oceny zawartych w tabeli 3. Wyniki badań zastosowania metody quick testu zawarto w tabelach 5 i 7, natomiast podsumowanie tych badań przedstawiono w tabelach 6 i 8 . 
Tabela 5. Wyniki zastosowania metody quick testu w przedsiębiorstwach zaliczonych do grupy ,dobrych”

\begin{tabular}{|c|c|c|c|c|c|c|c|c|c|c|c|c|c|c|c|}
\hline \multirow{2}{*}{ Nazwa spółki } & \multicolumn{3}{|c|}{ W1 } & \multicolumn{3}{|c|}{ W2 } & \multicolumn{3}{|c|}{ W3 } & \multicolumn{3}{|c|}{ W4 } & \multicolumn{3}{|c|}{$\sum$} \\
\hline & 2010 & 2011 & 2012 & 2010 & 2011 & 2012 & 2010 & 2011 & 2012 & 2010 & 2011 & 2012 & 2010 & 2011 & 2012 \\
\hline Fota & 4 & 4 & 4 & 1 & 3 & 1 & 1 & 3 & 1 & 1 & 2 & 1 & 7 & 12 & 7 \\
\hline Sfinks & 1 & 1 & 1 & 4 & 2 & 3 & 1 & 1 & 1 & 1 & 1 & 1 & 7 & 5 & 6 \\
\hline Intakus & 4 & 1 & 1 & 3 & 1 & 1 & 2 & 1 & 1 & 3 & 1 & 1 & 12 & 4 & 4 \\
\hline Drewex & 3 & 1 & 1 & 1 & 1 & 1 & 1 & 1 & 1 & 1 & 1 & 1 & 6 & 4 & 4 \\
\hline Monnari & 4 & 5 & 5 & 1 & 1 & 4 & 5 & 1 & 5 & 1 & 1 & 4 & 11 & 8 & 18 \\
\hline Advadis & 5 & 1 & 1 & 1 & 1 & 1 & 1 & 1 & 1 & 1 & 1 & 1 & 8 & 4 & 4 \\
\hline Interbud-lublin & 3 & 3 & 3 & 5 & 3 & 2 & 5 & 5 & 1 & 5 & 4 & 2 & 18 & 15 & 8 \\
\hline Internet group & 1 & 1 & 1 & 1 & 0 & 0 & 1 & 1 & 5 & 1 & 1 & 5 & 4 & 3 & 11 \\
\hline Dom development & 4 & 4 & 5 & 3 & 5 & 4 & 3 & 5 & 5 & 4 & 5 & 5 & 14 & 19 & 19 \\
\hline Elektrim & 3 & 3 & 5 & 5 & 5 & 5 & 3 & 1 & 5 & 5 & 1 & 5 & 16 & 10 & 20 \\
\hline Euromark & 5 & 4 & 2 & 0 & 1 & 5 & 1 & 1 & 1 & 1 & 1 & 1 & 7 & 7 & 9 \\
\hline Jago & 2 & 1 & 1 & 1 & 1 & 0 & 1 & 1 & 1 & 1 & 1 & 1 & 5 & 4 & 3 \\
\hline $\begin{array}{l}\text { Kompania } \\
\text { węglowa }\end{array}$ & 2 & 2 & 2 & 1 & 5 & 1 & 1 & 5 & 2 & 1 & 4 & 1 & 5 & 16 & 6 \\
\hline Mci & 5 & 5 & 5 & 1 & 1 & 1 & 5 & 3 & 5 & 1 & 3 & 5 & 12 & 12 & 16 \\
\hline Mostostal & 3 & 2 & 1 & 1 & 5 & 5 & 5 & 1 & 1 & 3 & 1 & 1 & 12 & 9 & 8 \\
\hline Pronox & 1 & 1 & 1 & 1 & 1 & 5 & 1 & 1 & 1 & 1 & 1 & 1 & 4 & 4 & 8 \\
\hline Poslkie jadło & 5 & 4 & 1 & 1 & 2 & 1 & 1 & 3 & 1 & 1 & 5 & 1 & 8 & 14 & 4 \\
\hline Ssi & 5 & 3 & 2 & 4 & 5 & 5 & 2 & 4 & 5 & 2 & 2 & 3 & 13 & 14 & 15 \\
\hline Mediatel & 1 & 2 & 3 & 1 & 1 & 5 & 1 & 1 & 1 & 1 & 5 & 5 & 4 & 9 & 14 \\
\hline $\begin{array}{l}\text { Fabryka maszyn } \\
\text { Ożarów }\end{array}$ & 1 & 3 & 5 & 0 & 0 & 1 & 3 & 4 & 1 & 0 & 3 & 1 & 4 & 10 & 8 \\
\hline Vistula & 4 & 4 & 5 & 5 & 5 & 5 & 1 & 1 & 2 & 1 & 1 & 1 & 11 & 11 & 13 \\
\hline Polimex-mostostal & 3 & 3 & 2 & 5 & 5 & 1 & 3 & 1 & 1 & 5 & 5 & 5 & 16 & 14 & 9 \\
\hline Orbis & 5 & 5 & 5 & 1 & 5 & 1 & 1 & 5 & 4 & 5 & 5 & 5 & 12 & 20 & 15 \\
\hline Dss & 3 & 1 & 1 & 1 & 5 & 1 & 3 & 1 & 1 & 5 & 5 & 5 & 12 & 12 & 8 \\
\hline Waśpol & 2 & 2 & 0 & 3 & 1 & 0 & 1 & 1 & 0 & 5 & 5 & 0 & 11 & 9 & 0 \\
\hline Duda & 3 & 4 & 4 & 5 & 5 & 1 & 5 & 3 & 1 & 5 & 1 & 1 & 18 & 13 & 7 \\
\hline $\mathrm{Pbg}$ & 3 & 4 & 1 & 1 & 0 & 0 & 5 & 5 & 1 & 4 & 5 & 5 & 13 & 14 & 7 \\
\hline Jw. Construction & 3 & 3 & 3 & 4 & 2 & 2 & 5 & 3 & 1 & 5 & 3 & 1 & 17 & 11 & 7 \\
\hline Abm solid & 2 & 2 & 5 & 3 & 3 & 5 & 2 & 5 & 5 & 2 & 1 & 1 & 9 & 11 & 16 \\
\hline Call 2 action & 5 & 5 & 4 & 3 & 5 & 5 & 1 & 5 & 1 & 3 & 5 & 1 & 12 & 20 & 11 \\
\hline $\begin{array}{l}\text { Energomontaż } \\
\text { południe }\end{array}$ & 2 & 2 & 5 & 4 & 3 & 5 & 5 & 5 & 5 & 1 & 1 & 1 & 12 & 11 & 16 \\
\hline Gant dewelopment & 4 & 4 & 2 & 2 & 3 & 5 & 1 & 3 & 5 & 1 & 1 & 1 & 8 & 11 & 13 \\
\hline Odlewnie polskie & 2 & 2 & 3 & 3 & 5 & 5 & 2 & 5 & 5 & 2 & 4 & 4 & 9 & 16 & 17 \\
\hline Pbo anioła & 2 & 3 & 3 & 4 & 3 & 2 & 5 & 5 & 3 & 4 & 5 & 3 & 15 & 16 & 11 \\
\hline Prochem & 5 & 5 & 5 & 5 & 5 & 4 & 3 & 3 & 2 & 3 & 3 & 1 & 16 & 16 & 12 \\
\hline Synkret & 2 & 2 & 5 & 4 & 3 & 5 & 5 & 5 & 5 & 4 & 3 & 1 & 15 & 13 & 16 \\
\hline Orzeł & 3 & 4 & 2 & 2 & 5 & 1 & 1 & 4 & 5 & 1 & 1 & 1 & 7 & 14 & 9 \\
\hline
\end{tabular}

Źródło: opracowanie własne na podstawie załącznika (tabela 1). 
W tabeli 6 przedstawiono podsumowanie danych z tabeli 5. Znalazły się w niej informacje o liczbie firm ze wskazaną liczbą uzyskanych punktów po zastosowaniu kryteriów oceny z metody quick testu zawartych w tabeli 2.

Tabela 6. Liczba firm z grupy sklasyfikowanych jako „dobre” ze wskazaniem rodzaju kondycji finansowej po zastosowaniu metody quick testu

\begin{tabular}{|c|r|r|r|c|}
\hline \multirow{2}{*}{$\begin{array}{c}\text { Kryterium oceny }- \\
\text { liczba uzyskanych } \\
\text { punktów }\end{array}$} & \multicolumn{3}{|c|}{ Liczba firm } & \multirow{2}{*}{ Kondycja finansowa } \\
\cline { 2 - 5 } & 2010 & 2011 & 2012 & bardzo dobra \\
\hline $17-20$ & 23 & 21 & 17 & dobra \\
\hline $13-16$ & 8 & 10 & 14 & dostateczna \\
\hline $9-12$ & 4 & 4 & 6 & zła/niekorzystna \\
\hline $5-8$ & 2 & 2 & 0 & bardzo zła \\
\hline $0-4$ & 0 & 0 & 0 & Zno \\
\hline
\end{tabular}

Źródło: opracowanie własne.

Analiza danych z tabeli 6 pozwala stwierdzić, że w grupie 37 spółek giełdowych zdefiniowanych jako „dobre” najwięcej jest takich, które zostały zdiagnozowane przez metodę quick testu jako podmioty o bardzo dobrej i dobrej kondycji finansowej. W latach 2010-2012 znalazło się w grupie przedsiębiorstw „dobrych” 31 spółek giełdowych o bardzo dobrej i dobrej kondycji finansowej, czyli $84 \%$ badanej próby badawczej. Pozostałe 16\% spółek otrzymało ocenę dostateczną i złą. W analizowanej próbie badawczej sklasyfikowanej wśród przedsiębiorstw „dobrych" nie znalazła się żadna ze wskazaniem na bardzo złą kondycję finansową. Sytuacja finansowa badanej grupy spółek na przestrzeni lat 2010-2012 uległa nieznacznym zmianom. Spada liczba spółek posiadających kondycję bardzo dobrą, natomiast wzrasta liczba spółek mających kondycję dobrą. Widoczne jest również przesunięcie spółek, które osiągnęły w latach 2010-2011 wyniki na poziomie kondycji złej, do poziomu kondycji dostatecznej. Można wysunąć wniosek, że badana grupa spółek „dobrych” w 84\% została sklasyfikowana prawidłowo już we wstępnej klasyfikacji. 
Tabela 7. Wyniki zastosowania metody quick testu w przedsiębiorstwach zaliczonych do grupy „złych”

\begin{tabular}{|c|c|c|c|c|c|c|c|c|c|c|c|c|c|c|c|}
\hline \multirow{2}{*}{ Nazwa spółki } & \multicolumn{3}{|c|}{ W1 } & \multicolumn{3}{|c|}{ W2 } & \multicolumn{3}{|c|}{ W3 } & \multicolumn{3}{|c|}{ W4 } & \multicolumn{3}{|c|}{$\sum$} \\
\hline & 2010 & 2011 & 2012 & 2010 & 2011 & 2012 & 2010 & 2011 & 2012 & 2010 & 2011 & 2012 & 2010 & 2011 & 2012 \\
\hline Eurocash & 2 & 2 & 2 & 3 & 3 & 2 & 5 & 3 & 5 & 2 & 2 & 2 & 12 & 10 & 11 \\
\hline Kernel & 5 & 5 & 5 & 5 & 5 & 4 & 5 & 5 & 5 & 5 & 5 & 5 & 20 & 20 & 19 \\
\hline Lentex & 5 & 5 & 5 & 5 & 5 & 5 & 2 & 5 & 5 & 2 & 5 & 4 & 14 & 20 & 19 \\
\hline PEP & 5 & 5 & 5 & 5 & 5 & 1 & 5 & 5 & 5 & 5 & 5 & 5 & 20 & 20 & 16 \\
\hline Plast-Box & 5 & 5 & 5 & 2 & 3 & 4 & 1 & 3 & 3 & 2 & 3 & 3 & 10 & 14 & 15 \\
\hline Próchnik & 5 & 5 & 5 & 0 & 5 & 4 & 1 & 1 & 1 & 2 & 1 & 2 & 8 & 12 & 12 \\
\hline Trans POLONIA & 4 & 4 & 4 & 5 & 5 & 5 & 5 & 5 & 5 & 4 & 5 & 4 & 18 & 19 & 18 \\
\hline ULMA & 5 & 5 & 5 & 2 & 4 & 3 & 5 & 5 & 3 & 5 & 5 & 4 & 17 & 19 & 15 \\
\hline Unibep & 3 & 3 & 3 & 5 & 5 & 3 & 5 & 5 & 3 & 5 & 5 & 5 & 18 & 18 & 14 \\
\hline Unima 2000 & 5 & 5 & 5 & 4 & 1 & 5 & 1 & 4 & 4 & 1 & 3 & 3 & 11 & 13 & 17 \\
\hline Alma & 3 & 3 & 3 & 2 & 2 & 3 & 2 & 2 & 2 & 1 & 1 & 2 & 8 & 8 & 10 \\
\hline Mennica & 5 & 5 & 5 & 5 & 5 & 5 & 5 & 5 & 5 & 4 & 4 & 4 & 19 & 19 & 19 \\
\hline Boryszew & 2 & 2 & 2 & 3 & 5 & 3 & 5 & 5 & 3 & 3 & 4 & 2 & 13 & 16 & 10 \\
\hline Famur & 5 & 5 & 5 & 5 & 5 & 5 & 5 & 5 & 5 & 5 & 5 & 5 & 20 & 20 & 20 \\
\hline AssecoBusiness & 5 & 5 & 5 & 5 & 5 & 5 & 5 & 5 & 5 & 5 & 5 & 5 & 20 & 20 & 20 \\
\hline Intercars & 4 & 4 & 4 & 4 & 5 & 4 & 5 & 5 & 5 & 5 & 5 & 5 & 18 & 19 & 18 \\
\hline Lotos & 4 & 3 & 4 & 5 & 5 & 2 & 5 & 2 & 5 & 3 & 2 & 2 & 17 & 12 & 13 \\
\hline Orlen & 4 & 4 & 5 & 5 & 4 & 4 & 5 & 4 & 4 & 3 & 2 & 2 & 17 & 14 & 15 \\
\hline PGE & 5 & 5 & 5 & 5 & 5 & 5 & 5 & 5 & 5 & 5 & 5 & 5 & 20 & 20 & 20 \\
\hline Synthos & 5 & 5 & 5 & 5 & 5 & 5 & 5 & 5 & 5 & 5 & 5 & 5 & 20 & 20 & 20 \\
\hline Apator & 5 & 5 & 5 & 1 & 1 & 1 & 5 & 5 & 5 & 5 & 5 & 5 & 16 & 16 & 16 \\
\hline Azoty & 5 & 5 & 5 & 1 & 1 & 1 & 5 & 5 & 5 & 5 & 5 & 5 & 16 & 16 & 16 \\
\hline Cam & 5 & 5 & 5 & 1 & 1 & 1 & 2 & 1 & 2 & 5 & 5 & 5 & 13 & 12 & 13 \\
\hline Grupa Kęty & 5 & 5 & 5 & 1 & 1 & 1 & 5 & 5 & 5 & 5 & 5 & 5 & 16 & 16 & 16 \\
\hline Kruk & 4 & 3 & 3 & 1 & 1 & 1 & 5 & 5 & 5 & 5 & 5 & 5 & 15 & 14 & 14 \\
\hline Mo Bruk Sa & 5 & 4 & 4 & 5 & 2 & 5 & 5 & 3 & 2 & 5 & 5 & 5 & 20 & 14 & 16 \\
\hline Netia & 5 & 5 & 5 & 5 & 5 & 1 & 5 & 5 & 1 & 5 & 5 & 5 & 20 & 20 & 12 \\
\hline Stomil Sanok & 5 & 5 & 5 & 5 & 5 & 5 & 5 & 5 & 5 & 5 & 5 & 5 & 20 & 20 & 20 \\
\hline Asseco & 5 & 5 & 5 & 5 & 5 & 5 & 5 & 5 & 5 & 5 & 5 & 5 & 20 & 20 & 20 \\
\hline Zetkama & 5 & 5 & 5 & 1 & 5 & 5 & 4 & 5 & 5 & 5 & 5 & 5 & 15 & 20 & 20 \\
\hline $\mathrm{CCC}$ & 5 & 5 & 5 & 5 & 5 & 5 & 5 & 5 & 5 & 5 & 5 & 4 & 20 & 20 & 19 \\
\hline ENEA & 5 & 5 & 5 & 5 & 5 & 5 & 5 & 5 & 5 & 5 & 5 & 5 & 20 & 20 & 20 \\
\hline KGHM & 5 & 5 & 5 & 5 & 5 & 5 & 5 & 5 & 5 & 5 & 5 & 5 & 20 & 20 & 20 \\
\hline Polsat & 4 & 3 & 2 & 5 & 3 & 1 & 5 & 5 & 5 & 5 & 4 & 5 & 19 & 15 & 13 \\
\hline Wawel & 5 & 5 & 5 & 0 & 5 & 5 & 5 & 5 & 5 & 5 & 5 & 5 & 15 & 20 & 20 \\
\hline Wojas & 3 & 3 & 3 & 3 & 3 & 3 & 3 & 1 & 3 & 3 & 1 & 2 & 12 & 8 & 11 \\
\hline LPP & 5 & 5 & 5 & 5 & 5 & 5 & 5 & 5 & 5 & 4 & 5 & 5 & 19 & 20 & 20 \\
\hline
\end{tabular}

Źródło: opracowanie własne. 
W tabeli 8 przedstawiono podsumowanie danych z tabeli 7. Znalazły się w niej informacje o liczbie firm ze wskazaną liczbą uzyskanych punktów po zastosowaniu kryteriów oceny z metody quick testu zawartych w tabeli 2.

Tabela 8. Liczba firm z grupy sklasyfikowanych jako „złe”

ze wskazaniem rodzaju kondycji finansowej po zastosowaniu metody quick testu

\begin{tabular}{|c|r|r|r|c|}
\hline \multirow{2}{*}{$\begin{array}{c}\text { Kryterium oceny } \\
\text { liczba uzyskanych punktów }\end{array}$} & \multicolumn{3}{|c|}{ Liczba firm } & \multirow{2}{*}{ Kondycja finansowa } \\
\cline { 2 - 5 } & 2010 & 2011 & 2012 & \\
\hline $17-20$ & 1 & 3 & 4 & bardzo dobra \\
\hline $13-16$ & 9 & 10 & 9 & dobra \\
\hline $9-12$ & 12 & 14 & 7 & dostateczna \\
\hline $5-8$ & 11 & 4 & 10 & zła/niekorzystna \\
\hline $0-4$ & 4 & 6 & 5 & bardzo zła \\
\hline
\end{tabular}

Źródło: opracowanie własne.

Na podstawie danych z tabeli 8 , w której znalazły się spółki giełdowe we wstępnej ocenie sklasyfikowane jako „złe”, należy stwierdzić, że w tym przypadku metoda quick testu nie zweryfikowała poprawnie kondycji finansowej badanej grupy spółek. Wśród spółek z postawionym, wnioskiem o upadłość bądź likwidację, znalazły się takie, które zostały ocenione bardzo dobrze, dobrze i dostatecznie. Stanowiły one 60\% w 2010 roku, 73\% w 2011 roku i 54\% w 2012 roku ogółu spółek giełdowych. Zmiana w sytuacji finansowej badanych przedsiębiorstw na przestrzeni okresu też nie potwierdza faktu, że kondycja badanej grupy spółek powinna być najgorsza w 2012 roku, ponieważ w tym czasie było tyle samo spółek, które otrzymały negatywną ocenę (złą i bardzo złą kondycję finansową), jak w latach 2010 i 2011 roku. Dlatego też metoda quick testu zastosowana w tej grupie badawczej nieprawidłowo sygnalizuje o jej problemach finansowych.

\section{Podsumowanie}

Celem artykułu było zweryfikowanie przydatności zastosowania metody quick testu do oceny sytuacji finansowej. Przydatność metody quick testu oceniono na podstawie dwóch grup przedsiębiorstw: 37 „dobrych” i 37 „złych”. Analiza wyniku zastosowania metody quick testu pozwoliła zdiagnozować kondycję finansową 
badanych spółek giełdowych. W przypadku spółek giełdowych ocenionych jako „dobre”, we wstępnej klasyfikacji, metoda quick testu sprawdziła się, jednak przy ocenie spółek giełdowych, których stan raczej nie budził wątpliwości, iż są one w złej kondycji finansowej, metoda quick testu mylnie zdiagnozowała ich stan finansowy. W związku z tym postawiona teza badawcza, mówiąca o tym, że metoda quick testu z wybraną grupą wskaźników umożliwia prawidłowe zdiagnozowanie kondycji finansowej przedsiębiorstw, jest fałszywa. Na brak możliwości wykorzystania metody quick testu z wybranymi wskaźnikami do diagnozowania w sposób prawidłowy kondycji finansowej spółek giełdowych mają wpływ: zły dobór wskaźników oraz przyjęte normy, ale również ograniczenia analizy wskaźnikowej, wśród których wymienia się wiarygodność danych finansowych (oszustwa księgowe).

\section{Literatura}

Analiza finansowa przedsiębiorstwa, red. M. Hamrol, Wydawnictwo Akademii Ekonomicznej w Poznaniu, Poznań 2004.

Gabrusewicz W., Analiza finansowa przedsiębiorstwa. Teoria i zastosowanie, PWE, Warszawa 2014.

Gołębiewski G., Tłaczała A., Analiza ekonomiczno-finansowa w ujęciu praktycznym, Difin, Warszawa 2005.

Helfert E.A., Techniki analizy finansowej, PWE, Warszawa 2004.

Mączyńska E., Ocena kondycji przedsiębiorstwa, „Życie Gospodarcze” 1994, nr 38.

Mioduchowska-Jaroszewicz E., Metody i kierunki analizy wypłacalności przedsiębiorstw, Wydawnictwo Naukowe Uniwersytetu Szczecińskiego, Szczecin 2005.

Mioduchowska-Jaroszewicz E., Model Altmana jako jedna z metod oceny wyptacalności przedsiębiorstw, „Prace Instytutu Ekonomiki i Organizacji Przedsiębiorstw” nr 329, red. W. Janasz, Wydawnictwo Naukowe Uniwersytetu Szczecińskiego, Szczecin 2002.

Mioduchowska-Jaroszewicz E., Poziom zadtuzenia w spótkach sektora budowlanego, w: Zarzadzanie finansami. Zarzadzanie ryzykiem i kreowanie wartości, red. D. Zarzecki, Wydawnictwo Naukowe Uniwersytetu Szczecińskiego, Szczecin 2007.

Mioduchowska-Jaroszewicz E., Zastosowanie quick testu do oceny spótek giełdowych sektora spożywczego, w: Perspektywy rozwoju rachunkowości, auditingu i analizy finansowej, red. J. Gierusz, Uniwersytet Gdański, Sopot 1999.

Siemińska E., Metody pomiaru i oceny kondycji przedsiębiorstwa, Wydawnictwo Uniwersytetu Toruńskiego im. Mikołaja Kopernika w Toruniu, Toruń 2002. 
Sierpińska M., Jachna T., Ocena przedsiębiorstwa wedlug standardów światowych, PWE, Warszawa 2001.

Urbańczyk E., Metody ilościowe w analizie finansowej, Wydawnictwo Naukowe Uniwersytetu Szczecińskiego, Szczecin 1998.

Waśniewski T., Skoczylas W., Syntetyczna ocena wyników oraz sytuacji finansowej przedsiębiorstwa, „Rachunkowość” 1998, nr 4.

Waśniewski T, Skoczylas W., Kierunki analizy finansowej w przedsiębiorstwie, Wyższa Szkoła Administracji Publicznej, Szczecin 1996.

\title{
DIAGNOSIS OF FINANCIAL POSITION LISTED COMPANIES BY QUICK TEST
}

\begin{abstract}
The aim of this article is to verify the suitability of the method quick test to assess the financial situation on the basis of two groups of companies: 37 "good" and 37 "bad". Companies admitted to the base of the "good" were characterized by achieving a profit, the company "bad" were put into receivership. The research thesis was, placed in an article that the method of quick test with selected four indicators (self-financing, coverage of interest, return on assets and the cost level) makes it possible to assess the financial condition of enterprises properly. The studies indicated that the thesis is false, which means that the method of quick test with a select group of indicators makes it possible to correctly diagnose the financial condition of enterprises.
\end{abstract}

\section{Translated by Edyta Mioduchowska-Jaroszewicz}

Keywords: financial position, quick test method, the financial indicators, listed companies JEL codes: G32, G33 